J. Clin. Chem. Clin. Biochem.

Vol. 19, 1981, pp. 1039-1041

\title{
Reference Values of Renal Excretion of Fluoride
}

\author{
By W. Massmann
}

\section{Institut für Arbeits- und Sozialhygiene, Karlsruhe}

(Received October 10, 1980/February 20, 1981)

Summary: Fluoride was measured in the spontaneous urine of a group of persons $(n=397)$ occupationally non-exposed to fluoride. At a concentration $<2 \cdot 10^{-4} \mathrm{~g} / \mathrm{kg}$ fluoride in drinking water the mean fluoride excretion in urine is $0.61 \mathrm{mg} / \mathrm{F}$ with an upper limit of $2.00 \mathrm{mg} / 1 \mathrm{~F}$. The 95 -percentile of normal fluoride excretion is $1.0 \mathrm{mg} / 1 \mathrm{~F}$. By correcting the values for the specific gravity of 1.024 the mean value of the fluoride excretion is $0.74 \mathrm{mg} / \mathrm{l} \mathrm{F}$ with an upper limit of $3.9 \mathrm{mg} / 1 \mathrm{~F}$. The measured $\mathrm{pH}$ and calcium contents had no influence on the fluoride excretion.

\section{Referenzwerte für die renale Fluorid-Ausscheidung}

Zusammenfassung: An einem beruflich nichtexponierten Kollektiv $(n=397)$ wurde die renale Fluorid-Ausscheidung im Spontanurin gemessen. Bei einer Fluoridkonzentration $<2 \cdot 10^{-4} \mathrm{~g} / \mathrm{kg}$ Trinkwasser betrug die mittlere F-Ausscheidung $0,61 \mathrm{mg} / \mathrm{l}$ bei einer oberen Grenze von $2,0 \mathrm{mg} / 1$. Das 95 -Perzentil der normalen Fluorid-Ausscheidung lag bei $1,0 \mathrm{mg} / 1$. Bei Umrechnung auf die Dichte 1,024 war der Mittelwert $0,74 \mathrm{mg} / \mathrm{l} \mathrm{F}$ und die obere Grenze 2,4 mg/1 F. Der pH-Wert und der Calciumgehalt der Urine hatten keinen Einfluß auf die F-Ausscheidung.

\section{Introduction}

The fluoride concentration in urine depends on the fluoride concentration in the drinking water $(1-3)$ and on the daily diet (4). The normal range of fluoride excretion is not certain, but a knowledge of its value is important for epidemiological studies and industrial hygiene practice, especially at low fluoride exposure levels, e.g. in welders and aluminium foundry workers.

In the available studies on the fluoride excretion of exposed workets the data were sometimes compared with small reference groups of non-exposed persons $(5,6)$. The results, however, do not allow a general conclusion; the same is true of laboratory studies (7).

In the present study, the urinary specific gravity, $\mathrm{pH}$, creatinine and calcium were measured, and since there are close chemical and metäbolic relations between fluoride and calcium, correlations were sought between these parameters and the measured fluoride excretion.

In addition, fluoride was determined in the drinking water of the areas where the workers live and work.

\section{Materials and Methods}

The group studied consisted of 397 healthy industrial workers, 104 females and 293 males of different ages (17-67 years), with no exposure to fluoride. All of them live and work in different regions of Germany. They were selected through the law of probability. The size of the collective consists of about 50000 workers. Independent of the time of the day, the working shift and the food intake, spontaneous urines (spot samples) were collected without preservative in polyethylene urine bottles. The time between urine collection and chemical analysis was always within 48 hours.

\section{Fluoride}

The fluoride concentration in urine was determined with the fluoride specific ion electrode (8).

$\mathrm{CV}=1.7 \% \quad \mathrm{CL}_{95 \%}=0.04$

$\left(\mathrm{CL}_{95 \%}=\right.$ confidence interval of the mean value at basis $\left.95 \%\right)$.

The density was determined with an aerometer.

For correcting the concentrations to the density 1.024 we used the formula ( 9 )

$$
x=\frac{0.024 \cdot F[\mathrm{mg} / \mathrm{l}]}{\text { density (urine) }-1}
$$

pH

High ohm single cell electrode.

Creatinine

According to Jaffe (10) urine dilution 1:50, CV $=4.1 \%$.

Calcium

Atomic absorption spectrophotometry at $422.8 \mathrm{~nm}$ dilution $1: 100, \mathrm{CV}=2.1 \%$.

The listed coefficients of variation are respectively related to the error of series determination. 


\section{Results}

Fluoride concentration, $[\mathrm{mg} / \mathrm{l}] \mathrm{F}$, in the urine of men and women: $\mathrm{n}=397, \overline{\mathrm{x}}=0.61, \mathrm{~s}=0.27, \mathrm{CL}_{95 \%}=0.028$, $\mathrm{CV}=44.3 \%$ 95-percentile $=1.0$. Range (men and women [mg/l] F): 0.10-2.00 uncorrected; $0.11-3.90$ corrected for density.

The fluoride excretion in men and women, and the corrected values with respect to density and creatinine excretion are shown in table 1.

The correlations of fluoride with creatinine, $\mathrm{pH}$ and calcium are shown in table 2 .

To prevent the influence of dilution, fluoride, creatinine and calcium were related to the density 1.024.

Tab. 1. Fluoride excretion $[\mathrm{mg} / \mathrm{l}] \mathrm{F}$ related to density and creatinine excretion in men and women.

\begin{tabular}{llll}
\hline $\begin{array}{l}\text { Un- } \\
\text { corrected }\end{array}$ & $\begin{array}{l}\text { Related } \\
\text { to density } \\
1.024\end{array}$ & $\begin{array}{l}\text { Related to } \\
\text { the crea- } \\
\text { tinine-con- } \\
\text { centration } \\
\text { (fluoride/ } \\
\text { creatinine } \\
\text { ratio) }\end{array}$ \\
& & & \\
& &
\end{tabular}

\begin{tabular}{lccc}
\hline Men [mg/l] F & \multicolumn{3}{l}{} \\
$\mathrm{n}$ & 293 & 239 & 262 \\
$\overline{\mathrm{x}}$ & 0.62 & 0.74 & 0.54 \\
$\mathrm{~s}$ & 0.29 & 0.27 & 0.29 \\
$\mathrm{CV}(\%)$ & 46.1 & 36.5 & 54.4 \\
$\mathrm{CL} 95 \%$ (mean value) & 0.033 & 0.034 & 0.035 \\
median & 0.55 & 0.58 & 0.51 \\
95-percentile & 1.0 & 1.11 & 1.36 \\
range & $0.12-2.0$ & $0.2-2.46$ & $0.2-1.71$ \\
& & & \\
Women [mg/l] $\mathrm{F}$ & & & \\
$\mathrm{n}$ & 104 & 71 & 98 \\
$\overline{\mathrm{x}}$ & 0.52 & 0.68 & 0.53 \\
$\mathrm{~s}$ & 0.27 & 0.28 & 0.29 \\
$\mathrm{CV}$ (\%) & 52.2 & 41.2 & 54.2 \\
CL95\% (mean value) & 0.052 & 0.065 & 0.056 \\
median & 0.41 & 0.55 & 0.39 \\
95-percentile & 1.03 & 1.35 & 1.08 \\
range & $0.1-1.52$ & $0.11-3.9$ & $0.07-1.4$ \\
\hline
\end{tabular}

Tab. 2. Pearson correlation coefficient (r), test of significance $\left(t_{0}\right)$ and significance level $(p)$.

\begin{tabular}{lccc}
\hline Correlation & F-Creatinine & F-pH & F-Ca \\
\hline Men & & & $\ldots$ \\
I & 0.18 & -0.04 & 0.25 \\
$\mathrm{t}_{0}$ & 1.81 & -0.39 & 2.56 \\
$\mathrm{p}(\%)$ & $<5$ & $>5$ & $<1$ \\
$\mathrm{n}$ & 100 & 100 & 100 \\
& & & \\
Women & & & \\
$\mathrm{I}$ & 0.47 & 0.19 & 0.24 \\
$\mathrm{t}_{0}$ & 4.67 & 1.77 & 2.36 \\
$\mathrm{p}(\%)$ & $<0.1$ & $<5$ & $<5$ \\
$\mathrm{n}$ & 79 & 86 & 86 \\
\hline
\end{tabular}

The fluoride content of the drinking water was determined in 13 samples at different regions where the studied workers live. The level was always below $2 \cdot 10^{-4} \mathrm{~g} / \mathrm{kg}$.

\section{Discussion}

In accordance with the low fluoride concentration in the drinking water the F excretion in urine was low. Our results correspond to other studies (3). Zober et al. (6) found $0.5 \mathrm{mg} / 24 \mathrm{~h}(\mathrm{n}=9)$. The results of balance studies (drinking water, food intake/urine) cannot directly be compared with the present study, because $24 \mathrm{~h}$-samples were always used $(2,4,11)$.

In epidemiological and industrial hygiene practice 24 h-collection of urine is not realistic. As Largent \& Fernau (12) showed (tab. 3) the spot-sample-technique is quite reliable. When the $\mathrm{F}$ concentration is corrected to the density of the urine it becomes even more exact (13).

Buchhold (14) corrected the fluoride concentration for a density of 1.016. Elkins et al (13) screened 35506 urine samples and found that the values have to be corrected for a density of 1.024 .

In the present study correction for density resulted in a smaller deviation and in a reduction of the difference in the $\mathrm{F}$ excretion of men and women, which were significantly different ( $t$-test; $99 \%$ level of significance) before correction for density. The correction of the $F$ excretion on the basis of the urinary creatinine concentration, however, proved to be less satisfactory. The standard deviation of the creatinine determination is higher than the standard deviation of the $F$ determination, so that e.g. the deviation of the $\mathrm{F} /$ creatinine quotient is higher than the $F$ excretion $[\mathrm{mg} / \mathrm{l}]$ in the urine.

A statistically significant, though slight, correlation has been found between $F$ and creatinine and $F$ and calcium. Since the $\mathrm{F}$ excretion also depends on the $\mathrm{F}$ content of drinking water we can say in summary that where the drinking water was $<2 \cdot 10^{-4} \mathrm{~g} / \mathrm{kg}$ the most frequent

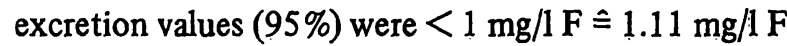
(men) and $1.35 \mathrm{mg} / \mathrm{l} \mathrm{F}$ (women) corrected for a density of 1.024 .

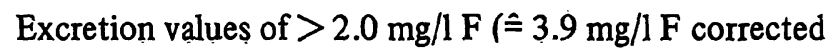
for a density of 1.024) probably represent the result of another, non-alimentary, F-uptake.

Tab. 3. Comparison of the $\mathrm{F}$ excretion in $24 \mathrm{~h}$-urine and in spotsamples (without correction for density) (12).

\begin{tabular}{|c|c|c|c|c|c|c|}
\hline \multirow[t]{2}{*}{. } & \multicolumn{2}{|c|}{$\begin{array}{l}24 \text { h-urine } \\
\text { [mg/l] F }\end{array}$} & \multirow[b]{2}{*}{ s } & \multicolumn{2}{|c|}{$\begin{array}{l}\text { Spot-samples } \\
\text { [mg/l] F }\end{array}$} & \multirow[b]{2}{*}{$s$} \\
\hline & $\mathrm{n}$ & $\overline{\mathbf{x}}$ & & $\mathrm{n}$ & $\overline{\mathbf{x}}$ & \\
\hline not & & & $\cdot$ & & & \\
\hline exposed & 17 & 0.44 & 0.18 & 17 & 0.38 & 0.14 \\
\hline exposed & 18 & 17.77 & 3.35 & 18 & .18 .00 & 6.68 \\
\hline
\end{tabular}




\section{References}

1. Hodge, H. C. \& Smith, F. A. (1965), Biological effects of inorganic fluorides Fluorine Chemistry, New York, Academic Press.

2. McClure, F. D. \& Kinser, C. A. (1944), Publ. Health Rep. (Wash.) 59, 1575-1591.

3. NIOSH (1975), Criteria for a recommended standard. Occupational exposure to inorganic fluorides U.S. Department of Health, Education and Welfare. Public Health Service Center of Disease Control. National Institute for Occupational Safety and Health.

4. Spencer, H., Lewin, I., Histrowski, E. \& Samackson, J. (1970), Am. J. Med. 49, 807-813.

5. Fabri, L., De Rosa, E., Potenza, I., Mapp, Ch., Rossi, A., Brighenti, F. \& Forin, F. (1978), Med. Lavoro 69, 594-604.

6. Zober, A., Geldmacher-v. Mallinckrodt, M. \& Schaller, L. H. (1977), Int. Arch. Occup. Environ. Health 40, 13-23.

7. Crosby, N. D. \& Sheppherd, P. A. (1957), Med. J. Austr. 44, 341-346.
8. Zober, A. \& Schaller, K. H. (1976), Fluorid-Bestimmung im Harn, Analytische Methoden, Bd. 2, Analysen im biol. Material Kommission zur Prüfung gesundheitsschädlicher Arbeitsstoffe der DFG Arbeitsgruppe Analy tische Chemie Weinheim Verlag Chemie.

9. Elkins, H. B. \& Pagnotto, L. D. (1969), Arch. Environ. Health 18, 996-1001.

10. Jaffé, M. (1886), Hoppe-Seyler's Z. Physiol. Chem. 10, 391.

11. Machle, W. \& Largent, E. J. (1943), J. Ind. Hyg. Toxicol. 25, $112-123$.

12. Largent, E. J. \& Fernau, I. F. (1944), J. Ind. Hyg. Toxicol. $26,113-116$.

13. Elkins, H. B., Pagnotto, L. D. \& Smith, H. L. (1974), Am. Ind. Hyg. Ass. J. 35, 559-565.

14. Buchhold, H. (1964), Ann. Occup. Hyg. 7, 125-136.
Dr. med. Walter Massmann Institut für Arbeits- und Sozialhygiene (IAS) gemeinnützige Stiftung

Daimlerstraße 7

D-7500 Karlsruhe 
